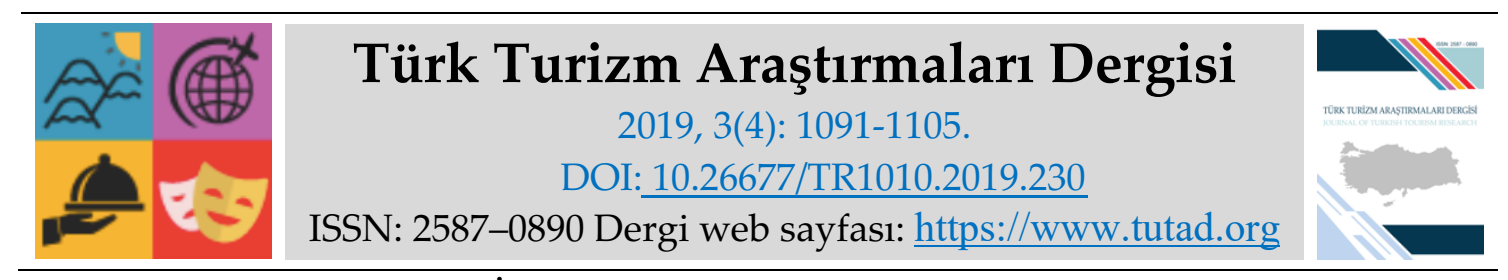

ARAȘTIRMA MAKALESI

\title{
Otel İşletmeleri Departman Performanslarının Müşteri Memnuniyeti Üzerindeki Etkileri: 5 Yıldızlı Bir Otelde Uygulama
}

Dr. Öğr. Üyesi Özgür DAVRAS, Süleyman Demirel Üniversitesi, İ.İ.B.F. Turizm İşletmeciliği Bölümü, Isparta, e-posta: ozgurdavras@sdu.edu.tr

ORCID: https://orcid.org/0000-0001-9037-4193

Yunus Emre BİLGIÇ, Süleyman Demirel Üniversitesi, Sosyal Bilimler Enstitüsü Yüksek Lisans Öğrencisi, Isparta, e-posta: y-e-bilgic@outlook.com

ORCID: https://orcid.org/0000-0002-3779-8082

$\ddot{O} z$

Otel işletmelerin iş performanslarını artırmaları ve finansal başarı elde edebilmeleri müşteri memnuniyeti sağlayabilmeleri ile doğru orantılıdır. Müşteri memnuniyeti ise otel işletmelerinin sunmuş oldukları hizmetlerin kalitesine bağlı olmaktadır. Bu araştırmada, otel işletmelerine bağlı tüm departman ve departmanlara ait alt birimlerin hizmet performanslarının müşteri memnuniyeti üzerindeki etkilerini belirlenmesi amaçlanmışır. Bu amaçla, Kuşadası bölgesinde faaliyet göstermekte olan beş yıldızlı bir otel işletmesinin müşterilerine uyguladığı anket formundan yararlanılmış olup, toplam 291 kişiden veri elde edilmiştir. Elde edilen verilere çok değişkenli regresyon analizi, t-testi ve tek yönlü varyans analizi uygulanmıştır. Analiz sonuçlarına göre, alışveriş merkezi ve ana restoran hizmet birim performanslarının müşteri memnuniyetini en fazla etkileyen birimler olduğu tespit edilmiştir. Diğer taraftan müşteri memnuniyetine en az etkiyi ise sırası ile Fitness Center, Balık restoran ve Kat hizmetleri birimlerinin yaptığı anlaşılmıştır. Ayrıca birimlerin hizmet performansının müşterilerin milliyetleri, otele geliş sayıları ve otelde konaklama sürelerine göre farklılaştığı da tespit edilmiştir.

Anahtar Kelimeler: Otel İşletmeleri Departmanları, Hizmet Kalitesi, Müşteri Memnuniyeti. Makale Gönderme Tarihi: 19.07.2019

Makale Kabul Tarihi: 04.10.2019

\footnotetext{
Önerilen Atıf:

Davras, Ö. ve Bilgiç, Y. E. (2019). Otel İşletmeleri Departman Performanslarının Müşteri Memnuniyeti Üzerindeki Etkileri: 5 Yıldızlı Bir Otelde Uygulama, Türk Turizm Araştırmaları Dergisi, 3(4): 1091-1105.

(C) 2019 Türk Turizm Araştırmaları Dergisi.
} 


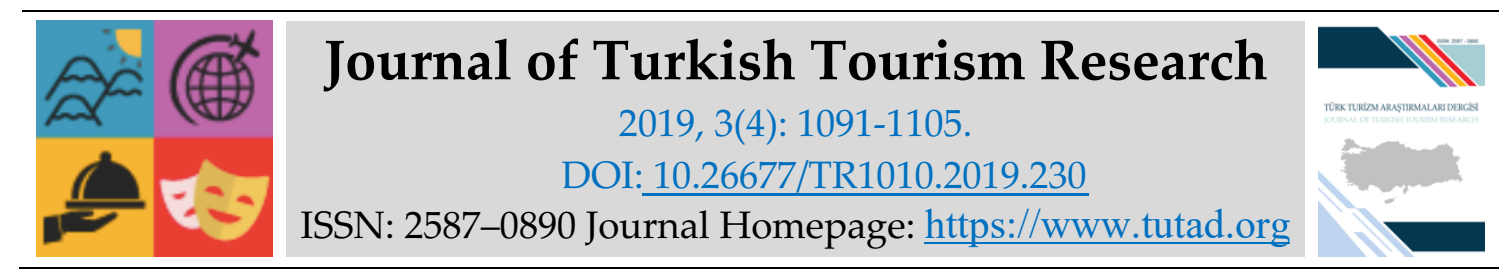

RESEARCH PAPER

\title{
The Effects of Hotel Business Department Performances on Customer Satisfaction: Application in a 5 Star Hotel
}

Assistant Prof. Dr. Özgür DAVRAS, Süleyman Demirel University, Faculty of Economics and Administrative Sciences, Isparta, e-mail: ozgurdavras@sdu.edu.tr

ORCID: https://orcid.org/0000-0001-9037-4193

Yunus Emre BİLGİÇ, MSc, Süleyman Demirel University, Social Sciences Institute, Isparta, email: y-e-bilgic@outlook.com

ORCID: https://orcid.org/0000-0002-3779-8082

\begin{abstract}
Increasing business performance and achieving financial success of hotel businesses is directly proportional to providing customer satisfaction. Customer satisfaction depends on the quality of the services provided by the hotel businesses. In this research, it is aimed to determine the effects of service performances of all departments and sub-units of hotel departments on customer satisfaction. For this purpose, a questionnaire form applied to the customers of a five-star hotel operating in Kuşadası region was utilized and questionnaire was filled out to 291 people. Multivariate regression analysis, $t$ test and One-way Anova analysis were applied to obtained data. According to the analysis results, shopping center and main restaurant services are the units that affect customer satisfaction the most. On the other hand, Fitness Center, Fish restaurant and Housekeeping units make the least impact on customer satisfaction. In addition, the service performance of the units varies according to the nationality, the number of arrivals to the hotel and the length of the stay of the customer.
\end{abstract}

Keywords: Hotel Business Departments, Service Quality, Customer Satisfaction

Received: 19.07.2019

Accepted: 04.10.2019

\section{Suggested Citation:}

Davras, Ö. and Bilgiç, Y. E. (2019). The Effects of Hotel Business Department Performances on Customer Satisfaction: Application in a 5 Star Hotel, Journal of Turkish Tourism Research, 3(4): 10911105.

(c) 2019 Türk Turizm Araştırmaları Dergisi. 


\section{GİRIŞ}

Yoğun rekabetin yaşandığı turizm sektöründe, otel işletmelerinin rekabet üstünlüğü kurabilmeleri ve finansal performanslarını artırabilmeleri müşteri memnuniyetini sağlayabilmelerine bağlı olmaktadır (Deng, Kuo ve Chen, 2008). Müşteri memnuniyeti ise işletme tarafından sunulan yüksek hizmet kalitesi ile mümkün olmaktadır. Otel işletmelerinde hizmetler işletme bünyesinde bulunan departmanlar ve bu departmanlara bağlı alt birimler tarafından sağlanmaktadır. Otel işletmesi hizmet birimlerinin performansları, hizmet kalitesini olumlu ya da olumsuz yönde etkileyeceğinden dolayı müşteri memnuniyetinin belirleyicisi konumundadır. Otel işletmelerinde önbüro, kat hizmetleri, yiyecek içecek, animasyon, teknik servis ve SPA gibi departmanlar ve bu departmanlara bağlı alt birimler müşterilere doğrudan hizmet sunmaktadır. Tüm bu departmanlar tarafından sunulan hizmetlerin, müşteriler tarafından nasıl algılandığını bilmek ve müşteri istek ve ihtiyaçlarını daha iyi anlayabilmek amacıyla bu birimlerinin performansının belirlenmesi gerekmektedir. Bundan dolayı otel işletmesinde müşterilere hizmet sunan birimlerin performanslarının ölçülmesi ve bilinmesi önem arz etmektedir.

Otel işletmelerinde sunulan hizmet kalitesi, müşteri memnuniyetinin temel belirleyicisi olduğundan literatürde yoğun bir şekilde ele alınmıştır. Araştırmaların büyük bir çoğunluğunda hizmet kalitesi Servqual (Juwaheer, 2004; Öztürk ve Seyhan, 2005; Eleren ve Kılıç, 2007; Arpacı ve Batman, 2015;), Önem-Performans (Martin, 1995; Tekin, Kalkan ve Duman, 2014; Chen, Murphy ve Knecht, 2016), Analitik Hiyerarşi Süreci Yöntemi (Murat ve Çelik, 2007; Saaty, 2008), Servperf yöntemi (Uslu, 2013), Kano tekniği (Albayrak, 2015; Davras ve Caber, 2019) ve Entropi yöntemi (Korucuk, Akyurt ve Turpçu, 2019) gibi farklı tekniklerle genel boyutlarıyla ölçülmüştür. Sınırlı sayıdaki bazı çalışmalarda (Gundersen, Heide ve Olsson, 1996; Mohsin ve Lockyer, 2009) ise otel işletmelerinin hizmet kalitesi departman bazlı ölçülmüştür. Bu araştırmanın literatürdeki diğer çalışmalardan farkı, beş yıldızlı bir otel işletmesinin müşterilerine uyguladığı anket formundan faydalanarak, müşterilere hizmet sunan tüm departman ve departmanlara bağlı alt birimlerin performansları ölçülmüştür. Örneğin, literatürde genel olarak ele alınan personel boyutu, bu çalışmada her birim içinde müşteriler tarafından ayrı ayrı değerlendirilerek hizmet birimlerinin performansları ortaya koyulmuştur. Dolayısıyla otel yöneticileri müşterilere doğrudan ve dolaylı hizmet sunan tüm birimlerinin performanslarını değerlendirerek, kısıtlı kaynaklarını doğru ürünlere aktarabilecek ve performansı düşük olan birimlerin performansını artıracak gerekli politika ve strateji geliştirebileceklerdir.

Bu çalışmada Kuşadası beldesinde faaliyet göstermekte olan beş yıldızlı bir otel işletmesinin hizmet birimlerinin performansları incelenerek, her bir birimin müşteri memnuniyeti üzerindeki etkilerinin tespit edilmesi amaçlanmıştır. Bunun yanında hizmet birim performanslarının müşterilerin yerli ve yabancı olma durumu, otel işletmesine geliş sayıları ve otel işletmesinde konaklama sürelerine göre farklılaşıp farklılaşmadığı da araştırılmıştır.

\section{KURAMSAL ÇERÇEVE}

Son yıllarda iletişim, ulaşım, sağlık, turizm ve yiyecek içecek sektörü gibi hizmet ağırlıklı birçok alanın gelişim göstermesi, hizmet sektörünün de ekonomideki önemini ve hacmini artırmaktadır (Organ ve Soydaş, 2012). Hizmet sektöründe faaliyet göstermekte olan işletmeler sundukları hizmetler ile yaşamlarını sürdürdüklerinden dolayı, aynı alanda faaliyet gösteren hizmet sağlayıcılarının sayısının ve sundukları hizmet çeşitliliğinin artması, işletmelerin rakiplerine karşı üstünlük sağlayabilmek için sundukları hizmetlerin diğerlerinden farklı ve kaliteli olmasını zorunlu kılmaktadır. Hizmet sektörünün önemli parçalarından biri olan otel işletmelerinde de 
sunulan hizmetlerin dayanıksız olması, stoklanamaması ve soyut özellik göstermesi, bu tür işletmelerde hizmet kalitesinin önemini daha artırmaktadır.

Bir işletmenin müşteri beklentilerini karşılayabilme veya aşma yeteneği olarak tanımlanan hizmet kalitesi (Öztürk ve Seyhan, 2005), turizm alanında müşterilerin istek ve ihtiyaçları doğrultusunda müşterilerin beklentilerini karşlayabilecek uygun turistik mal ve hizmetlerin önceden belirlenerek, belli bir standart haline gelmiş sürekliliği ve tutarlılığı olan sunum şekli olarak tanımlanmaktadır (Murat ve Çelik, 2007). Hizmet kalitesinin düzeyi, müşterilerin aldıkları hizmetin ardından beklenti ve algılarını karşılaştırarak bir değerlendirme yapmaları sonucunda ortaya çıkmaktadır (Lee, Lee ve Yoo, 2000). Başka bir ifadeyle müşterilerin algıladıkları hizmet ve bunun sonucunda oluşan fikirleri hizmet kalitesini belirlemektedir. Algılanan hizmet kalitesi, müşterilerin almış oldukları hizmet neticesi sonucunda oluşan hisleridir ve müşteri memnuniyetini büyük oranda bu hisler belirlemektedir. Müşteriler tarafından algılanan hizmet kalitesi ise hizmetin soyut özellik göstermesinden dolayı değişkenlik gösterebilmektedir. Örneğin; herhangi bir otel çalışanın farklı müşterilere sunduğu aynı hizmet bir müşteride olumlu etki bırakırken diğer müşteride aynı etkiyi bırakmayabilir (Ghobadian, Speller ve Jones, 1994).

Algılanan hizmet kalitesi müşteri memnuniyetinin belirleyicisi olmasından dolayı, literatürdeki çalışmaların çoğunluğunda bu iki kavram arasındaki ilişki araştırılmıştır (Bekar ve Kılıç, 2015). Müşteri memnuniyeti, işletmelerin finansal başarıları, rekabet gücü ve karlılığı ardındaki itici güç olan müşteri memnuniyeti, hizmeti oluşturan farklı özelliklerin performanslarının genel olarak değerlendirilmesi olarak tanımlanmaktadır (Bartikowski ve Llosa, 2007). Otel işletmelerinin hizmet kalitesini artırması ile yüksek müşteri memnuniyeti sağlamaları kuvvetli olasılık olacaktır. Yüksek müşteri memnuniyeti ise işletmelere yeni müşteri kazandırmak ve müşteri sadakati oluşturmakla birlikte işletmelerin finansal performanslarını olumlu yönde etkileyecektir (Davras ve Caber, 2019). Dolayısıyla otel işletmeleri, müşterilerin ihtiyaç ve beklentilerini doğru bir şekilde tespit ederek, strateji ve politikalarını müşteri beklentilerine göre belirlemeleri gerekmektedir.

Otel işletmelerinde hizmet sunumlarının büyük bir çoğunluğu çalışanlar tarafından yapıldığı için hizmet kalitesinin düzeyi de çalışanların verimlilikleri ve memnuniyetleri ile doğru orantılıdır. Başka bir ifadeyle otel işletmelerinin çalışanlarına gereken değeri ve önemi göstermeleri ile daha yüksek hizmet kalitesi sağlayabileceklerdir. Örneğin Uslu, Kutukız ve Çeken (2013) otel işletmelerinde verilen hizmet içi eğitimin çalışanların verimlilikleri artırarak işletmedeki hizmet kalitesinin yükseldiğini ortaya koymuşlardır. Diğer taraftan işletmelerin çalışan memnuniyeti sağlamalarının müşteri memnuniyetini artırdığı (Spinelli ve Canavos, 2000) ve işletmelerin finansal performanslarını dolaylı olarak etkilediği (Chi ve Gürsoy, 2009) de tespit edilmiştir. Bundan dolayı otel işletmelerinin çalışanlarına yönelik yapacağı yatırımlarla, onları memnun etmeleri hem hizmet kalitesinin artmasına hem de buna bağlı olarak müşteri memnuniyeti ve karlılıkların artmasına neden olacağı söylenebilir.

Otel işletmelerinde hizmet kalitesi ve müşteri memnuniyeti arasındaki ilişkiler turizm literatüründe yoğun bir şekilde ele alınmıştır. Bu araştırmaların bazıları Tablo 1'de özetlenmiştir. Tablo incelendiğinde, otel işletmelerinin önemli faaliyetlerini yerine getiren yiyecek-içecek ve önbüro departmanlarının hizmetleri ile otel işletmeleri için büyük önem taşıyan personelin niteliklerinin, müşteri memnuniyetinin belirleyicileri olduğu ön plana çıkmaktadır. Bu sonucun ortaya çıkmasındaki nedin de otel işletmelerinde hizmetlerin büyük bir bölümünün personel tarafından sunulması ve temel hizmetlerin (konaklama ve yeme-içme) önbüro ve yiyecek-içecek departmanları tarafından sağlanmasından kaynaklandığını söylemek mümkündür. 
Tablo 1. Otel İşletmelerinde Müşteri Memnuniyetinin Belirleyicilerine Yönelik Literatür Taraması

\begin{tabular}{|c|c|c|}
\hline Yil & Yazar & Müşteri Memnuniyetini Belirleyen Faktörler \\
\hline 1996 & Gundersen vd. & Önbüro (soyut hizmetler)- Kat hizmetleri (somut hizmetler) \\
\hline 2001 & Choi ve Chu & Personel hizmetleri \\
\hline 2008 & Ekinci, Daves ve Massey & Fiziksel özellikler- Personel hizmetleri \\
\hline 2009 & Mohsin ve Lockyer & Önbüro - Oda servisi - Restoran hizmetleri \\
\hline 2010 & Özer ve Günaydın & Önbüro - Mutfak hizmetleri \\
\hline 2010 & Emir, Kılıç ve Pelit & Yiyecek-içecek hizmetleri - Çamaşırhane hizmetleri \\
\hline 2013 & Curakovic vd. & Önbüro \\
\hline 2013 & Öztürk ve Kenzhebayeva & Kat hizmetleri - Personel hizmetleri \\
\hline 2013 & Markovic ve Jankovic & Güvenilirlik - Erişebilirlik - Somut özellikler \\
\hline 2013 & Grobelna ve Marciszewska & Personel hizmetleri \\
\hline 2014 & Tekin vd., & Yiyecek-içecek hizmetleri \\
\hline 2014 & Güven ve Sarışık & Fiziksel özellikler, Heveslilik - Güvenilirlik \\
\hline 2014 & Suki & Empati - Somut özellikleri \\
\hline 2015 & Albayrak ve Caber & Yiyecek-içecek hizmetleri - Personel hizmetleri \\
\hline 2015 & Arpacı ve Batman & Güven \\
\hline 2015 & Albayrak & Plaj \\
\hline 2016 & Ilban vd., & Güven - Empati \\
\hline 2016 & Kuo, Chen ve Boger & Personel hizmetleri - yiyecek içecek hijyeni \\
\hline 2016 & Şirin ve Aksu & Empati \\
\hline 2019 & Mun, Woo, ve Paek & Yiyecek-içecek hizmetleri \\
\hline 2019 & Davras ve Caber & Animasyon hizmetleri \\
\hline
\end{tabular}

\section{YÖNTEM}

$\mathrm{Bu}$ araştırma, Kuşadası turizm beldesinde faaliyet göstermekte olan beş yıldızlı bir otel işletmesinin müşterilerine uygulamakta olduğu anket formundan yararlanılarak gerçekleştirilmiştir. Örnek alınan otel işletmesi bünyesinde önbüro, kat hizmetleri, misafir ilişkileri, SPA merkezi, animasyon, teknik servis ve alışveriş merkezi departmanları bulunmaktadır. Bunun yanı sıra yiyecek_içecek departmanına bağlı olarak, bir adet ana restoran, bir adet snack restoran, dört adet A'la Carte restoran (İtalyan, Balık, Uzak-Doğu ve Türk restoran olmak üzere) ve üç adet bar (loby, pool ve snack bar olmak üzere) hizmet vermektedir. Bu tüm birimlerin hizmet performanslarını ölçmek amacıyla oluşturulan anket formu, birimlerin hizmet performanslarını ölçen 83 ve katılımcıların kişisel özelliklerini belirlemeye yönelik 6 olmak üzere toplam 89 ifadeden oluşmaktadır. Otel hizmet birimlerinin performansını ve genel müşteri memnuniyetini belirlemeye yönelik oluşturulan ifadeler 5'li Likert ölçeği (1: hiç memnun değilim, 2: memnun değilim, 3: ne memnunum ne memnun değilim, 4: memnunum, 5:oldukça 
memnunum) ile ölçülmüştür. Otel işletmesinde Nisan -Mayıs 2019 döneminde konaklayan müşterilerden 291'i anket formunu doldurmuş olup, bu anketler değerlendirmeye alınmıştır.

Araştırmada öncelikle katılımcıların kişisel özelliklerini belirlemek için frekans analizi yapılmıştır. Daha sonra otel hizmet birimlerinin boyutlu yapısını tespit etmek amacıyla Faktör analizi gerçekleştirilmiştir. Araştırmanın ana amacı olan hizmet birimlerinin müşteri memnuniyeti üzerinde etkilerini belirlemek amacıyla çok değişkenli regresyon analizi uygulanmıştır. Son olarak hizmet birimlerinin performansları ve müşteri memnuniyeti, katılımcıların milliyetleri ve otele geliş sayılarına göre karşılaştırmak amacıyla t testi ve tek yönlü varyans analizlerinden faydalanılmıştır.

\section{BULGULAR}

Araştırmaya katılanların kişisel özellikleri tanımlayıcı istatistik kapsamında Tablo 1'de sunulmuştur.

Tablo 1. Katılımcıların Kişisel Özellikleri

\begin{tabular}{lll|lll}
\hline Cinsiyet & $\mathbf{N}$ & $\mathbf{\%}$ & Medeni Hal & $\mathbf{N}$ & $\mathbf{\%}$ \\
\hline Erkek & 146 & 51,4 & Evli & 69 & 24,1 \\
Kadın & 138 & 48,6 & Bekâr & 217 & 75,9 \\
Toplam & 284 & 100 & Toplam & 286 & 100 \\
\hline Yaş & $\mathbf{N}$ & $\mathbf{\%}$ & Konaklama Süresi & $\mathbf{N}$ & $\mathbf{\%}$ \\
\hline 30 yaş ve altı & 45 & 15,7 & 1 -6 gün & 165 & 58,9 \\
$31-45$ yaş arası & 182 & 63,7 & $7-13$ gün & 77 & 27,5 \\
46 yaş ve üstü & 59 & 20,6 & 14 gün ve üzeri & 38 & 13,6 \\
Toplam & 286 & 100 & Toplam & 280 & 100 \\
\hline Turist türü & $\mathbf{N}$ & $\mathbf{\%}$ & Otele Geliş Sayısı & $\mathbf{N}$ & \% \\
\hline Yerli turist & 204 & 70,3 & İlk kez & 221 & 76,2 \\
Yabancı turist & 86 & 29,7 & 2 ve üstü & 69 & 23,8 \\
Toplam & 290 & 100 & Toplam & 290 & 100 \\
\hline
\end{tabular}

Katılımcıların çoğunluğunu cinsiyete göre erkekler (\%51,4), medeni duruma göre bekarlar $(\% 75,9)$, yaşa göre 31-45 yaş arası grup $(\% 63,7)$ oluşturmaktadır. \%70,3'ü yerli turist geri kalan $\% 29,7$ 'sini Avrupalı katılımclardır. Büyük bir çoğunluğu $(\% 58,9) 1$ haftadan daha az konaklama yapmıştır. \%76,2'si otele ilk kez gelenler olup, \%23,8'i daha önce otelde konaklamışlardır.

Otel işletmesi konsepti dahilinde hizmet veren birimlerin performansını ölçmeye yönelik oluşturulan toplam 83 ifadeyi daha az sayıda değişkene indirmek ve sonraki analizler için ölçeğin boyutlu yapısını oluşturmak amacıyla açıklayıcı faktör analizi gerçekleştirilmiştir. Ölçekte yer alan 82 ifade faktör analizine dâhil edilmiş, eş kökenliliği 0,5'in altında ve binişik durumda olan 5 ifadenin modelden çıkarılması sonucunda toplam varyansın $\% 76,47^{\prime}$ sini açıklayan ve özdeğeri 1 'in üstünde olan 16 boyut elde edilmiştir (Tablo 2). 
Tablo 2. Otel İşletmesi Hizmet Birimlerin Performansını Ölçen İfadelerin Boyutlu Yapısı

\begin{tabular}{|c|c|c|c|c|c|}
\hline Boyutlar & 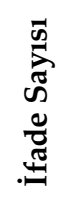 & 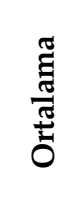 & 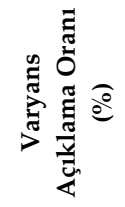 & 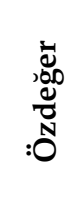 & 节 \\
\hline FAKTÖR 1: Alışveriş Merkezi & 10 & 4,08 & 8,39 & 6,46 & ,915 \\
\hline FAKTÖR 2: SPA & 7 & 4,18 & 8,02 & 6,18 & ,951 \\
\hline FAKTÖR 3: Pool ve Snack Bar & 6 & 4,42 & 5,81 & 4,48 & ,918 \\
\hline FAKTÖR 4: Animasyon & 5 & 4,47 & 5,60 & 4,31 & ,910 \\
\hline FAKTÖR 5: Ana Restoran & 5 & 4,12 & 5,22 & 4,02 & ,903 \\
\hline FAKTÖR 6: İtalyan Restoran & 4 & 4,37 & 5,02 & 3,86 & ,959 \\
\hline FAKTÖR 7: Teknik Servis & 5 & 4,39 & 4,94 & 3,80 & ,911 \\
\hline FAKTÖR 8: Kat Hizmetleri & 6 & 4,20 & 4,79 & 3,69 &, 866 \\
\hline FAKTÖR 9: Uzak-Doğu Restoran & 4 & 4,21 & 4,79 & 3,68 & ,946 \\
\hline FAKTÖR 10: Balık Restoran & 4 & 4,09 & 4,61 & 3,55 & ,943 \\
\hline FAKTÖR 11: Önbüro & 4 & 4,58 & 4,60 & 3,54 &, 864 \\
\hline FAKTÖR 12: Türk Restoran & 4 & 4,33 & 4,24 & 3,26 & ,949 \\
\hline FAKTÖR 13: Lobby Bar & 4 & 4,42 & 3,82 & 2,94 & ,901 \\
\hline FAKTÖR 14: Yan Hizmetler (TV, Internet vb.) & 4 & 4,06 & 2,62 & 2,02 & ,737 \\
\hline FAKTÖR 15: Misafir İlişkileri & 3 & 4,59 & 2,01 & 1,61 &, 795 \\
\hline FAKTÖR 16: Fitness Center & 2 & 4,06 & 1,85 & 1,25 & 864 \\
\hline
\end{tabular}

KMO =,907 ; Bartlett's Küresellik Testi= 24186,499 $(\mathrm{p}=, 000) \quad$ Toplam Varyans Açıklama: \% 76,47

Tablo 2' de, elde edilen boyutların isimleri, ortalamaları, varyans açıklama oranları ve güvenilirlik katsayıları yer almaktadır. Elde edilen güvenilirlik katsayılarına (,737- ,959 arasındaki değişen değerlere) göre her bir boyutun güvenilirlikleri sağlanmıştır. Her bir boyutun ortalama değerleri incelendiğinde, misafir ilişkileri ile önbüro departmanlarının en yüksek; fitness center, yan hizmetler ve alışveriş merkezi birimlerinin en düşük ortalama değerine sahip oldukları görülmektedir. Başka bir ifadeyle otel müşterileri en çok misafir ilişkileri ve önbüro departmanlarından memnun oldukları söylenebilir.

Araştırmanın temel amacı olan, otel hizmet birim performanslarının müşteri memnuniyeti üzerindeki etkilerini belirlemek amacıyla çok değişkenli regresyon analizi gerçekleştirilmiştir. Gerçekleştirilen analiz sonucunda, her bir boyuta ait elde edilen $t$ değerleri ile beta katsayıları Tablo 3'te gösterilmiştir. 
Tablo 3. Hizmet Birim Performanslarının Müşteri Memnuniyeti Üzerindeki Etkileri

\begin{tabular}{|c|c|c|c|}
\hline Hizmet Birimi & $\beta$ & $\mathbf{t}$ & p \\
\hline Alışveriş Merkezi & ,177 & 4,788 &, $000^{* *}$ \\
\hline SPA Hizmetleri & ,132 & 3,317 &, $001^{* *}$ \\
\hline Pool ve Snack Bar & ,100 & 2,275 &, $024^{*}$ \\
\hline Animasyon & ,130 & 4,070 &, $000^{* *}$ \\
\hline Ana Restoran & ,176 & 4,788 &, $000^{* *}$ \\
\hline İtalyan Restoran & 106 & 3,020 &, $003^{* *}$ \\
\hline Teknik Servis & ,067 & 1,835 & ,068 \\
\hline Kat Hizmetleri &, 093 & 2,704 &, $007^{* *}$ \\
\hline Uzak-Doğu Restoran &, 034 & ,902 & ,368 \\
\hline Balık Restoran & ,091 & 2,351 &, $019^{*}$ \\
\hline Önbüro Hizmetleri & ,035 & ,950 & ,343 \\
\hline Türk Restoran &,- 003 &,- 077 & ,939 \\
\hline Lobby Bar &, 066 & 1,419 & ,157 \\
\hline Yan Hizmetler & 140 & 3,824 &, $000^{* *}$ \\
\hline Misafir İlişkileri & ,001 &, 022 & ,983 \\
\hline Fitness Center & 081 & 2,203 &, $028^{*}$ \\
\hline
\end{tabular}

${ }^{*} \mathrm{p}<0,05 ; \quad{ }^{* *} \mathrm{p}<0,01 \quad \mathrm{R}^{2}: 0,779 ; \quad \mathrm{F}: 60,520 \quad$ Bağımlı değişken: Genel olarak otelden memnun kaldım

Tablo 3 incelendiğinde, alışveriş merkezi, SPA hizmetleri, animasyon, ana restoran, İtalyan restoran, kat hizmetleri ve yan hizmetler boyutlarının standardize edilmiş beta katsayıları 0,01 seviyesinde, pool ve snack bar, balık restoran ve fitness center boyutlarının standardize edilmiş beta katsayıları 0,05 seviyesinde anlamlı oldukları görülmektedir. Diğer boyutların (teknik servis, uzak-doğu restoran, önbüro hizmetleri, Türk restoran, loby bar ve misafir ilişkileri) beta katsayıları istatistiki açıdan anlamsız bulunmuştur. Modelin bir bütün olarak anlamlı $(p=0,000)$ olduğu ve kullanılan bağımsız değişkenlerin müşteri memnuniyetini \%78 oranında açıkladığı tespit edilmiştir. Anlamlı bulunan boyutların beta katsayılarına göre, alışveriş merkezi ve ana restoran hizmet birim performanslarının müşteri memnuniyetini en fazla etkileyen birimler olduğu tespit edilmiştir. Bu birimleri sırasıyla yan hizmetler, SPA hizmetleri ve animasyon birimleri takip etmektedir. Diğer taraftan müşteri memnuniyetine en az etkiyi ise sırası ile fitness center, balık restoran ve kat hizmetleri birimlerinin yaptığı söylenebilir. Bu sonuç; restoran birimlerinin müşteri memnuniyetini etki eden üç faktörden biri olduğunu ortaya koyan Mohsin ve Lockyer (2009) ve yiyecek-içecek hizmetlerinin genel memnuniyet üzerinde etkili olduğunu tespit eden Albayrak ve Caber'in (2015) çalışmalarını desteklemesine rağmen, Gundersen vd., (1996) ve Curakovic vd.'nin (2013) çalışma sonuçları ile örtüşmemektedir. Diğer taraftan bu çalışmada personel davranışları her bir hizmet birimi içinde ayrı ayrı değerlendirildiğinden dolayı, personel boyutunun memnuniyet üzerinde en çok etkili olduğu belirleyen Ekinci vd. 
(2008), Choi ve Chu (2001) ile Albayrak ve Caber (2015) araştırma sonuçları sonuçlarını desteklediği de söylenebilir.

Hizmet birim performanslarının katılımcıların yerli ve yabancı olma durumuna göre farklılaşıp farklılaşmadığını belirlemek amacıyla tek bağımsız örneklem $t$ testi gerçekleştirilmiş olup, test sonuçları Tablo 4'te gösterilmiştir.

Tablo 4. Katılımcıların Turist Türü ile Hizmet Birim Performansları Arasındaki Farklılaşma Durumu

\begin{tabular}{|c|c|c|c|c|c|c|}
\hline \multirow[t]{2}{*}{ Hizmet Birimleri } & \multicolumn{2}{|c|}{ Yerli Turist } & \multicolumn{2}{|c|}{ Avrupalı Turist } & \multirow[b]{2}{*}{$\mathrm{t}$} & \multirow[b]{2}{*}{$\mathrm{p}$} \\
\hline & Ort & S.S. & Ort. & S.S. & & \\
\hline Alışveriş Merkezi & 4,14 & 467 & 4,10 &, 547 & ,630 &, 529 \\
\hline SPA Hizmetleri & 4,31 & 449 & 4,19 &, 553 & 1,882 & ,061 \\
\hline Pool ve Snack Bar & 4,61 &, 517 & 4,37 & 641 & 3,442 &, $001^{* *}$ \\
\hline Animasyon & 4,66 &, 534 & 4,48 &, 542 & 2,680 &, $008^{* *}$ \\
\hline Ana Restoran & 4,28 & ,861 & 4,21 & ,768 & ,630 &, 529 \\
\hline İtalyan Restoran & 4,49 & ,502 & 4,39 & 605 & 1,527 & ,128 \\
\hline Teknik Servis & 4,49 &, 433 & 4,52 & 499 &,- 493 & ,623 \\
\hline Kat Hizmetleri & 4,28 & ,776 & 4,27 & ,809 &, 067 & ,946 \\
\hline Uzak-Doğu Restoran & 4,28 &, 526 & 4,20 & 623 & 1,050 & ,295 \\
\hline Balık Restoran & 4,17 & 615 & 4,10 & 633 & ,906 & ,366 \\
\hline Önbüro Hizmetleri & 4,75 & 478 & 4,55 & 630 & 2,603 & $0,10^{*}$ \\
\hline Türk Restoran & 4,43 & 494 & 4,28 & 625 & 2,291 & $0,23^{*}$ \\
\hline Lobby Bar & 4,59 & 470 & 4,37 &, 582 & 3,346 &, $001^{* *}$ \\
\hline Yan Hizmetler & 4,19 & ,723 & 4,11 & ,734 & ,897 & ,370 \\
\hline Misafir İlişkileri & 4,70 &, 474 & 4,56 &, 536 & 2,116 & ,036 \\
\hline Fitness Center & 4,18 &, 539 & 3,98 & 673 & 2,583 & $0,10^{*}$ \\
\hline
\end{tabular}

${ }^{*} \mathrm{p}<0,05 \quad{ }^{* *} \mathrm{p}<0,01$

Tablo 4 incelendiğinde pool ve snack bar, animasyon, önbüro hizmetleri, Türk restoran, Lobby bar ve fitness center hizmet birim performansları ile katılımcıların yerli ve yabancı olma durumu arasında istatistiki açıdan anlamlı farklılık bulunduğu görülmektedir. Buna göre otel işletmesinde tüm bu hizmet birimlerinin performansları yerli turistler üzerinde daha fazla etkili olduğu söylenebilir. Diğer hizmet birimlerinde (A'la Carte restoran, alışveriş merkezi, SPA merkezi, ana restoran, havuz ve plaj bar, kat hizmetleri, teknik servis) istatistiki açıdan anlamlı farklılık bulunamamıştır.

Hizmet birim performanslarının katılımcıların otele geliş sayılarına göre farklılaşıp farklılaşmadığını belirlemek amacıyla tek bağımsız örneklem $t$ testi gerçekleştirilmiş olup, test sonuçları Tablo 5'te gösterilmiştir. 
Türk Turizm Araştırmaları Dergisi, 3(4): 1091-1105.

Tablo 5. Katılımcıların Otele Geliş Sayıları ile Birim Performansları Arasındaki Farklılaşma Durumu

\begin{tabular}{|c|c|c|c|c|c|c|}
\hline \multirow[t]{2}{*}{ Hizmet Birimleri } & \multicolumn{2}{|c|}{ İlk Kez } & \multicolumn{2}{|c|}{ Devamlı } & \multirow[b]{2}{*}{$\mathrm{t}$} & \multirow[b]{2}{*}{$\mathrm{p}$} \\
\hline & Ort & S.S. & Ort. & S.S. & & \\
\hline Alışveriş Merkezi & 4,12 &, 512 & 4,17 & ,419 &,- 725 & ,469 \\
\hline SPA Hizmetleri & 4,28 & ,483 & 4,27 & 489 & , 183 & ,855 \\
\hline Pool ve Snack Bar & 4,58 & ,554 & 4,40 & ,590 & 2,271 &, $024^{*}$ \\
\hline Animasyon & 4,60 & ,580 & 4,64 & ,397 &,- 550 &, 583 \\
\hline Ana Restoran & 4,32 & ,805 & 4,08 & ,902 & 2,103 &, $036^{*}$ \\
\hline İtalyan Restoran & 4,46 &, 542 & 4,46 &, 521 &, 020 & ,984 \\
\hline Teknik Servis & 4,52 & ,428 & 4,43 &, 523 & 1,426 & ,155 \\
\hline Kat Hizmetleri & 4,33 & ,747 & 4,11 & 880 & 2,003 &, $046^{*}$ \\
\hline Uzak-Doğu Restoran & 4,26 &, 540 & 4,26 & 612 &,- 061 & ,951 \\
\hline Balık Restoran & 4,14 & 652 & 4,16 &, 509 &,- 213 & 831 \\
\hline Önbüro Hizmetleri & 4,72 &, 513 & 4,62 &, 595 & 1,226 &, 221 \\
\hline Türk Restoran & 4,41 &, 539 & 4,33 &, 543 & 1,034 & ,302 \\
\hline Lobby Bar & 4,55 & ,479 & 4,42 & ,606 & 1,951 &, 052 \\
\hline Yan Hizmetler & 4,19 & ,743 & 4,09 & 669 & 1,043 & ,298 \\
\hline Misafir İlişkileri & 4,68 &, 482 & 4,62 &, 542 & ,801 &, 424 \\
\hline Fitness Center & 4,12 &, 584 & 4,10 & 604 & ,242 & 809 \\
\hline
\end{tabular}

${ }^{*} \mathrm{p}<0,05$

Tablo 5 incelendiğinde pool ve snack bar, ana restoran ve kat hizmetleri birim performansları ile katılımcıların otele geliş sayıları arasında istatistiki açıdan anlamlı farklılık bulunduğu görülmektedir. Buna göre otel işletmesinde bu birim hizmetlerin performanslarının otel işletmesine ilk kez gelenler üzerinde daha fazla etkili olduğu söylenebilir. Diğer geri kalan tüm hizmet birimlerinde istatistiki açıdan anlamlı farklılık bulunamamıştır.

Hizmet birim performanslarının katılımcıların otel işletmesinde konaklama sürelerine göre farklılaşıp farklılaşmadığını belirlemek amacıyla tek yönlü varyans analizi gerçekleştirilmiş olup, test sonuçları Tablo 6'da gösterilmiştir.

Tablo 6 incelendiğinde tüm hizmet birim performansları ile katılımcıların konaklama süreleri arasında istatistiki açıdan anlamlı farklılık bulunduğu görülmektedir. Anlamlı farklılı̆̆ın hangi gruplar arasında olduğunu tespit etmek amaciyla yapılan Post Hoc analizlerinden Tukey testi sonuçlarına göre, 7 günden daha az konaklama yapan katılımcıların 14 günden fazla konaklama yapan katılımcılara nazaran memnuniyet algılarının daha yüksek olduğu tespit edilmiştir. 
Tablo 6. Katılımcıların Konaklama Süreleri ile Birim Performansları Arasındaki Farklılaşma Durumu

\begin{tabular}{|c|c|c|c|c|c|}
\hline \multirow[t]{2}{*}{ Hizmet Birimleri } & \multicolumn{3}{|c|}{ Konaklama Süresi } & \multirow[b]{2}{*}{$\mathrm{F}$} & \multirow[b]{2}{*}{$\mathrm{p}$} \\
\hline & $<7$ gün & 8-13 gün & 14 gün< & & \\
\hline Alışveriş Merkezi & 4,17 & 4,15 & 3,93 & 3,756 &, $025^{*}$ \\
\hline SPA Hizmetleri & 4,35 & 4,27 & 4,01 & 7,882 &, $000^{* *}$ \\
\hline Pool ve Snack Bar & 4,68 & 4,50 & 4,02 & 28,674 &, $000^{* *}$ \\
\hline Animasyon & 4,67 & 4,60 & 4,29 & 8,001 &, $000^{* *}$ \\
\hline Ana Restoran & 4,34 & 4,30 & 3,77 & 7,806 &, $001^{* *}$ \\
\hline İtalyan Restoran & 4,55 & 4,42 & 4,19 & 8,034 &, $000^{* *}$ \\
\hline Teknik Servis & 4,54 & 4,57 & 4,19 & 11,569 &, $000^{* *}$ \\
\hline Kat Hizmetleri & 4,33 & 4,38 & 3,80 & 8,426 &, $000^{* *}$ \\
\hline Uzak-Doğu Restoran & 4,33 & 4,21 & 4,09 & 3,267 &, $040^{*}$ \\
\hline Balık Restoran & 4,24 & 4,14 & 3,74 & 10,372 &, $000^{* *}$ \\
\hline Önbüro Hizmetleri & 4,80 & 4,60 & 4,40 & 10,481 &, $000^{* *}$ \\
\hline Türk Restoran & 4,47 & 4,36 & 4,10 & 7,869 &, $000^{* *}$ \\
\hline Lobby Bar & 4,67 & 4,44 & 4,01 & 32,375 &, $000^{* *}$ \\
\hline Yan Hizmetler & 4,27 & 4,18 & 3,76 & 8,323 &, $000^{* *}$ \\
\hline Misafir İlişkileri & 4,78 & 4,56 & 4,34 & 15,853 &, $000^{* *}$ \\
\hline Fitness Center & 4,20 & 4,13 & 3,77 & 8,226 &, $000^{* *}$ \\
\hline
\end{tabular}

${ }^{*} \mathrm{p}<0,05 \quad{ }^{* *} \mathrm{p}<0,01$

\section{SONUÇ VE ÖNERILER}

$\mathrm{Bu}$ araştırmada, otel işletmelerinde departmanlara bağlı birimler tarafından sunulan hizmetlerin müşteri memnuniyeti üzerindeki etkileri incelenmiştir. Açıklayıcı faktör analizi sonucunda müşterilere hizmet sunan 16 hizmet birimi elde edilmiştir. Elde edilen bu hizmet birim performanslarının müşteri memnuniyeti üzerindeki etkilerini belirlemek amacıyla gerçekleştirilen çok değişkenli regresyon analiz sonuçları, alışveriş merkezi ve ana restoran hizmet birim performanslarının memnuniyeti en fazla etkileyen; Fitness Center, Balık restoran ve Kat hizmetleri birimlerinin ise memnuniyeti en az etkileyen birimler olduğunu ortaya koymuştur. Bu sonuca göre, otel işletmesinin alışveriş merkezi ve ana restoran birimlerinin performans düzeylerini aynen devam ettirmeleriyle ve fitness center, balık restoran ve kat hizmetleri birimlerinin performansını artırmaları ile daha yüksek müşteri memnuniyeti sağlamaları kuvvetli olasılık olacaktır.

Araştırmada gerçekleştirilen diğer analizler ( $\mathrm{t}$ testi ve tek yönlü varyans analizi) algılanan hizmet kalitesinin, müşterilerin pazar durumu, otele geliş sayıları ve otelde konakladıkları gün sayısına göre farklılaştığını ortaya koymuştur. Pool ve Snack bar, Animasyon, Önbüro hizmetleri, Türk restoran, Lobby bar ve Fitness Center birimlerinden algılanan hizmet kalitesi daha düşük olan yabancı müşteriler üzerinde yoğunlaşması otel işletmesinin yarar sağlayacaktır. Otele geliş 
sayılarına göre hizmet kalitesinin farklılaştığını belirleyen Eleren ve Kılıç (2007) çalışması ile örtüşen bu çalışmanın diğer bir sonucu, Pool ve Snack bar, Ana restoran ve Kat hizmetleri birimlerinden algılanan hizmet kalitesi devamlı müşterilerde daha düşük olduğunu ortaya koymuştur. Dolayısıyla otel işletmelerinin bu hizmet birimlerinde devamlı müşterilere daha özen göstermeleri gerekmektedir. Araştırmanın dikkat çeken diğer bir sonucu da otelde daha uzun süreli konaklayan (14 gün ve üzeri) müşterilerin tüm hizmet birimlerinde algıladığı hizmet kalitesinin daha kısa konaklayan (7 günden az) müşterilere göre daha düşük olmasıdır. Bu sonuca göre de otel işletmesinin daha uzun süreli konaklayan müşteriler tüm hizmet birim performanslarını artırmaları hem hizmet kalitesinin yükselmesine hem de müşteri memnuniyetinin artmasına neden olacaktır. Sonuç olarak, otel işletmelerinin daha yüksek müşteri memnuniyeti sağlayabilmeleri için yabancı müşterilerin, devamlı müşterilerin ve daha uzun süreli konaklayan müşterilerin beklentilerini karşılayabilmeleri ile mümkün olabilecektir.

Literatürde konu ile ilgili yapılan araştırmalar, otel işletmelerinde sunulan hizmetlerin kalitesi veya performansının müşteri memnuniyeti üzerindeki etkilerini ortaya koymuştur. Literatürdeki çalışmalardan farklı olarak bu araştırmada, otel işletmesinde müşteri memnuniyeti ölçülmesinde kullanılan anket formundan faydalanarak, her bir departman ve departmana bağlı alt birimlerin performansları irdelenerek, her bir hizmet biriminin memnuniyet üzerindeki etkileri incelenmiştir. $\mathrm{Bu}$ yönüyle bu araştırmanın literatüre derinlik katarak katkı sağlayacağ düşünülmektedir. Yönetimsel açıdan bakıldığında, araştırmanın sonuçları otel işletmesi yöneticilerine ürün geliştirme boyutu ile önemli katkılar sağlayabilir. Daha yüksek müşteri memnuniyetinin sağlanabilmesi için hangi hizmet birimlerine gerekli yatırımların yapılabileceği ve hangi müşteriler üzerinde yoğunlaşacağı konularında yol gösterici olacaktır.

Araştırmanın sadece bir otel işletmesinde ve Nisan-Mayıs 2019 döneminde yapılması, bu çalışmanın başlıca sınırını oluşturmaktadır. Ayrıca örneklemin kolayda örnekleme yöntemi ile seçilmiş olması, sonuçların genellenebilme gücünü zayıflatmaktadır. Farklı bir destinasyonda birden fazla otel işletmesinde veya farklı bir zaman dilimi içerisinde, tesadüfi örnekleme yöntemlerinden biri ile yapılması daha farklı sonuçların elde edilmesine imkân verecektir.

\section{KAYNAKÇA}

Albayrak, T. and Caber, M. (2015). Prioritisation of the Hotel Attributes According to Their Influence on Satisfaction: A Comparison of Two Techniques, Tourism Management, 46, 43-50.

Albayrak (2015). Ürün Özelliklerinin Performansı ile Müşteri Memnuniyeti Arasındaki Doğrusal ve Doğrusal Olmayan İlişkinin Karşılaştırılması, Anatolia: Turizm Araştırmaları Dergisi, 26(1): 17-28.

Arpacı, Ö. ve Batman, O. (2015). Helal Konseptli Otel İşletmelerinin Yüksek ve Düşük Sezonda Algılanan Hizmet Kalitesinin Müşteri Sadakati ve Müşteri Değerine Etkisi, Seyahat ve Otel İşletmeciliği Dergisi, 12(3): 73-86.

Bartikowski, B. and Llosa, S. (2007). Customer Satisfaction Measurement: Comparing Four Methods of Attribute Categorisations, The Service Industries Journal, 24(4), 67-82.

Bekar, A. ve Kılıç, B. (2015). Hizmet Kalitesi Memnuniyet İlişkisi: Üniversite Kampüsünde Faaliyet Gösteren Yiyecek İçecek İşletmelerinde Karşılaştırılmalı Bir Uygulama, Sosyal ve Beşeri Bilimler Araştırmaları Dergisi, (34), 1-24.

Chen, M.M., Murphy, C.H. and Knecht, S. (2016). An Importance Performance Analysis of Smartphone Applications for Hotel Chains, Journal of Hospitality and Tourism Management, 29: 6979. 
Chi, C.G. and Gürsoy, D. (2009). Employee Satisfaction, Customer Satisfaction, and Financial Performance: An Empirical Examination, International Journal of Hospitality Management, 28: $245-253$

Choi, T.Y. and Chu, R. (2001). Determinants of Hotel Guests' Satisfaction and Repeat Patronage in the Hong Kong Hotel Industry, Hospitality Management, 20: 277-297.

Curakovic, D., Sikora, I., Garaca, V., Curcic, N. and Vukasov S. (2013). The Degree of Consumer Satisfaction with Hotel Services, Journal of Tourism, 15: 6-11.

Davras, Ö. and Caber, M. (2019). Analysis of Hotel Services by Their Symmetric and Asymmetric Effects on Overall Customer Satisfaction: A Comparison of Market Segments, International Journal of Hospitality Management, 81: 83-93.

Deng, W.J., Kuo, Y.F. and Chen, W.C. (2008). Revised Importance-Performance Analysis: Three Factor Theory and Benchmarking, The Service Industries Journal, 28(1): 37-51.

Ekinci, Y., Daves, P.L. and Massey, G.R. (2008). An Extended Model of the Antecedents and Consequences of Consumer Satisfaction for Hospitality Services, European Journal of Marketing, 42(1/2): 35-68.

Eleren, A. ve Kılıç, B. (2007). Turizm Sektöründe SERVQUAL Analizi ile Hizmet Kalitesinin Ölçülmesi ve Bir Termal Otelde Uygulama, Afyon Kocatepe Üniversitesi, İ.I.B.F. Dergisi, 4(1): 235263.

Emir, O., Kılıç, G., ve Pelit, E. (2010). Üç Yıldızlı Otel İşletmelerinde Müşteri Memnuniyeti Üzerine Bir Araştırma, Süleyman Demirel Üniversitesi İktisadi ve İdari Bilimler Fakültesi Dergisi, 15(3): 291-310

Ghobadian, A., Speller, S., and Jones, M. (1994). Service quality: concepts and models. International Journal of Quality \& Reliability Management, 11(9): 43-66.

Grobelna, A. and Marciszewska, B. (2013). Measurement of Service Quality in the Hotel Sector: The Case of Northern Poland, Journal of Hospitality Marketing \& Management, 22(3): 313-332.

Gundersen, G.M., Heide, M., and Olsson, H.U. (1996). Hotel Guest Satisfaction Among Business Travelers, Cornell Hotel and Restaurant Administration Quarterly, April: 72-81.

Güven, E.Ö. ve Sarışık, M. (2014). Konaklama Hizmetlerinde Davranışsal Niyeti Etkileyen Hizmet Kalitesi Boyutları, İşletme Bilimi Dergisi, 2(2): 21-51.

Ilban, M.O., Bezirgan, M. ve Çolakoğlu, F. (2016). Termal Otellerinde Algılanan Hizmet Kalitesi, Memnuniyet ve Davranışsal Niyetler Arasındaki İlişkilerin İncelenmesi: Edremit Örneği, Anatolia: Turizm Araştırmaları Dergisi, 27(2): 181-194.

Juwaheer, D.T. (2004). Exploring International Tourists' Perceptions of Hotel Operations by Using a Modified SERVQUAL Approach: A Case Study of Mauritus, Managing Service Quality: An International Journal, 14(5): 350-364.

Korucuk, S., Akyurt, H. ve Turpçu, E. (2019). Otel İşletmelerinde Hizmet Kalitesinin Entropi Yöntemi ile Ölçülmesi: Giresun İlindeki Üç Yıldızlı Oteller Üzerine Bir Araştırma, Manas Sosyal Araştırmalar Dergisi, 8(1): 697-709.

Kuo, C.M., Chen, H.T. and Boger E. (2016). Implementing City Hotel Service Quality Enhancements: Integration of Kano and QFD Analytical Models, Journal of Hospitality Marketing \& Management, 25(6): 748-770. 
Lee, H., Lee, Y., and Yoo, D. (2000). The Determinants of Perceived Service Quality and Its Relationship with Satisfaction, Journal of Services Marketing, 14(3): 217-231.

Marković, S. and Janković, S.R. (2013). Exploring the Relationship Between Service Quality and Customer Satisfaction in Croatian Hotel Industry, Tourism and Hospitality Management, 19(2): 149164.

Martin, D.W. (1995). An Importance/Performance Analysis of Service Providers' Perception of Quality Service in the Hotel Industry, Journal of Hospitality \& Leisure Marketing, 3(1): 5-17.

Mun, S.G., Woo, L. and Paek, S. (2019). How Important is F\&B Operation in the Hotel Industry? Empirical Evidence in the US Market, Tourism Management, 75: 156-168.

Mohsin, A. and Lockyer, T. (2009). Customer Perceptions of Service Quality in Luxury Hotels in New Delhi, India: An Exploratory Study, International Journal of Contemporary Hospitality Management, 22(2), 160-173.

Murat, G., ve Çelik, N. (2007). Analitik Hiyerarşi Süreci Yöntemi ile Otel İşletmelerinde Hizmet Kalitesini Değerlendirme: Bartın Örneği, Uluslararası Yönetim İktisat ve İşletme Dergisi, 3(6), 1-20.

Organ, A., ve Soydaş, M. E. (2012). Yerli Turistlerin Hizmet Kalitesi ve Tekrar Ziyaret Niyetlerine Yönelik Tutumları: Karahayıt'ta Bir Uygulama, Pamukkale Üniversitesi Sosyal Bilimler Enstitüsü Dergisi, (12): 63-72.

Özer, Ö. ve Günaydın, Y. (2010). Otel İşletmelerinde Müşteri Memnuniyeti ve Müşteri Sadakati İlişkisi: Dört Yıldızlı Otel İşletmelerinde Bir Uygulama, Dokuz Eylül Üniversitesi İşletme Fakültesi Dergisi, 11(2): 127-154.

Öztürk, Y. ve Seyhan, K. (2005). Konaklama İşletmelerinde Sunulan Hizmet Kalitesinin Servqual Yöntemi ile Ölçülmesi, Anatolia: Turizm Araştırmaları Dergisi, 16(2): 170-182.

Öztürk, Y. ve Kenzhebayeva, A. (2013). Turizm Sektöründe Hizmet Kalitesi: Türkiye ve Kazakistan'daki Termal Otel İşletmelerinde Karşılaştırmalı Bir Araştırma: Journal of Tourism and Gastronomy Studies, 1(4): 35-46.

Saaty, T.L. (2008). Decision Making with the Analytic Hierarchy Process, International Journal of Services Sciences, 1(1): 83-98.

Spinelli, M.A. and Canavos, G.C. (2000). Investigating the Relationship Between Employee Satisfaction and Guest Satisfaction, Cornel Hotel and Restaurant Administration Quarterly, 41: 29-33.

Suki, N.M. (2014). Moderating Role of Gender in the Relationship Between Hotel Service Quality Dimensions and Tourist Satisfaction, Journal of Quality Assurance in Hospitality \& Tourism, 15(1): 44-62.

Şirin, M. E., ve Aksu, M. (2016). Otel İşletmelerinde Hizmet Kalitesinin Müşteri Memnuniyeti, Tekrar Satın Alma ve Tavsiye İsteği Üzerine Etkisi: Trabzon Ortahisar Örneği, Karabük Üniversitesi Sosyal Bilimler Enstitüsü Dergisi, 6(2), 530-544.

Tekin, Ö.A., Kalkan, G. ve Duman H. (2014). Hizmet Kalitesinin Önem-Performans Analizi il Ölçülmesi: Üniversite Sosyal Tesislerinin Konaklama Üniteleri Üzerine Bir Uygulama, Uluslararası Sosyal Araştırmalar Dergisi, 7(31): 751-770.

Uslu, A. (2013). Ankara Şehirlerarası Terminal İşletmesi Hizmet Kalitesinin Servperf Yöntemi ile Ölçülmesi, Uluslararası Akademik Yeni Fikir Dergisi, 5(10), 67-86. 
Uslu, A., Kutukız, D. ve Çeken, H. (2013). Otel İşletmelerinde Çalışan Personelin Aldığı Hizmet İçi Eğitimin Verimliliğe Etkisi, Verimlilik Dergisi, 7(2): 101-116. 